\title{
Pre-diagnostic role of platelet miRNA in coronary heart disease of healthy overweight subjects via platelet leptin receptor activation
}

\author{
Yakubu Abdulrahman ${ }^{1,2 \odot}$, Azrina Azlan ${ }^{3 \oplus}$, Loh Su Peng ${ }^{3 \oplus}$, Sabariah Md Noor ${ }^{1, *(\circledast)}$
}

${ }^{1}$ Department of Pathology, Faculty of

Medicine and Health Sciences, Universiti

Putra Malaysia 43400 Serdang,

Selangor, Malaysia

${ }^{2}$ Department of Haematology, Faculty of Medical Laboratory Science, Usmanu Danfodiyo University Sokoto, P.M.P 2346, Sokoto, Northern western Nigeria

${ }^{3}$ Department of Nutrition and Dietetics, Faculty of Medicine and Health Sciences, Universiti Putra Malaysia 43400 Serdang, Selangor, Malaysia

\section{Correspondence}

Sabariah Md Noor, Department of Pathology, Faculty of Medicine and Health Sciences, Universiti Putra Malaysia 43400 Serdang, Selangor, Malaysia

Email: md_sabariah@upm.edu.my History

- Received: Mar 19, 2019

- Accepted: Jun 17, 2019

- Published: Jun 30, 2019

DOI :

https://doi.org/10.15419/bmrat.v6i6.552

\section{Check for updates}

\section{Copyright}

(c) Biomedpress. This is an openaccess article distributed under the terms of the Creative Commons Attribution 4.0 International license.

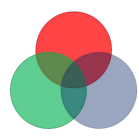

\begin{abstract}
Obesity and overweight have become a global problem that development of various coronary artery diseases (CAD), such as myocardial infarction, atherosclerosis and congestive heart failure. Effective diagnosis is needed for effective treatment and prevention, particularly in healthy overweight subject. Platelets is an important component of hemostatic balance, that maintains the coagulation physiology. Platelets are involved in different pathological events such as thrombosis and CAD in various inflammatory conditions. There are evidences that highlight an important role of miRNA in regulation of gene expression profiling in platelets. Current hypothesis has shown the likelihood of using miRNAs as diagnostic markers in the event of CAD. This review article describes the association between overweight/obesity and platelets activation in elucidating the gene expression profiling in platelet miRNAs in CAD patient. The application of platelet miRNAs as predictive markers in overweight/obese individuals may become a marginal milestone in the history of this diet-related disorder treatment.
\end{abstract}

Key words: Overweight, Obesity, Platelet activation marker, Platelet miRNA, Coronary Artery Disease.

\section{INTRODUCTION}

Overweight is a major public health issue, which affects conspicuous portion of the world population. It constitutes a risk factor for metabolic events that predispose an individual to diabetes, hypertensions and atherosclerosis. Overweight has been recently linked to low grade chronic inflammatory diseases, like type 2 diabetes, cardiovascular disease and cancer. However, acute inflammatory responses are important for defensive and homeostatic mechanisms of healing, repair and tissue regeneration ${ }^{1}$. Chronic inflammatory conditions include hypertension, diabetes, cardiovascular disorders (CVDs) and cancer ${ }^{2}$. A report by World Health Organization (WHO) in 2016 showed that over 1.9 billion adults above 18 were overweight worldwide, and 650 million adults were obese. These figures show, that $39 \%$ of adults $\geq$ 18 years of age (representing $40 \%$ women and $39 \%$ men) were overweight, while $13 \%$ of world adult population (representing $15 \%$ women and $11 \%$ men) were obese. Thus, from 1975 to $2016^{3}$, the global prevalence of overweight and obesity cases has nearly tripled. Epidemiological evidence and clinical studies have clearly demonstrated, that overweight predisposed an individual to an increased incidence of thrombotic occlusion, or atherosclerosis that corre- lated with epicardial fat thickness ${ }^{4}$ and visceral obesity ${ }^{5}$. Endothelial dysfunction, monocytes recruitment, inflammation and platelet activation are associated with dyslipidemia. Studies showed that leptin resistance could be a possible candidate that links obesity with cardiovascular diseases ${ }^{6-8}$. Meta-analysis data by Coronary Heart Prevention of West Scotland Studies suggested, that leptin could induce CHD independently ${ }^{9}$. Although, leptin receptor (ObRb) on platelet membrane can signal angiogenesis, regulate bone formation, accelerate vascular endothelial injuries and further enhance platelet aggregation via platelet leptin receptor ${ }^{10,11}$ (Figure 1).

Activated platelet releases cytokines, chemokines, hemostatic factor, adhesion protein, antigen receptor, mitogens and platelet miRNA ${ }^{12}$. Platelet miRNA gene expression pattern has been demonstrated to be more accurate and precise, compared to mRNA expression pattern in differentiation and characterizing various diseases (such as atherosclerosis, myocardial infarction and cancers ${ }^{13}$ ). Thus, this review article describes the relationship between overweight, leptin resistance, platelet activation and platelets miRNAs expression profiling, as well as to advocates the usefulness of miRNAs as predictive biomarkers of CAD in healthy overweight subjects. 


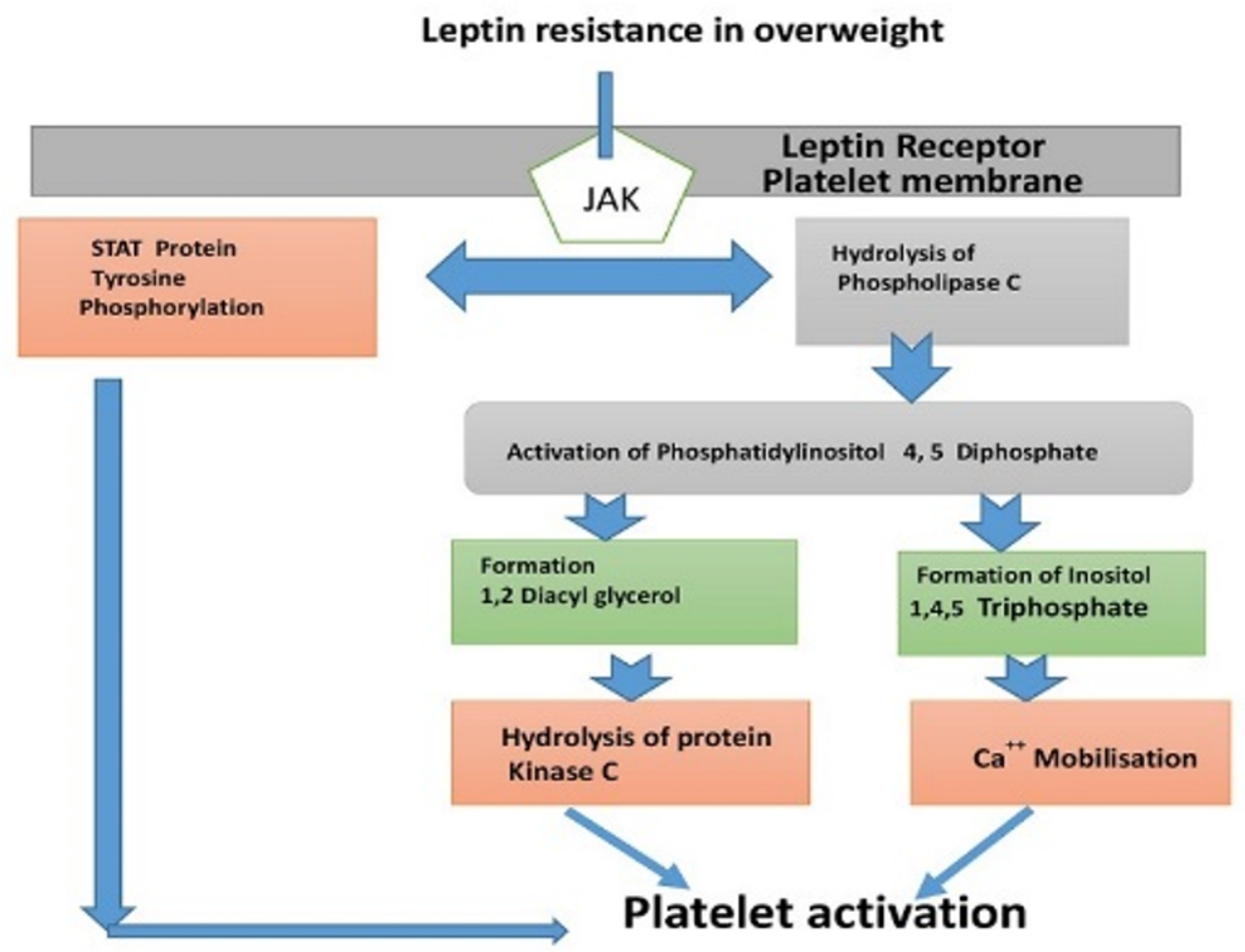

Figure 1: Proposed leptin-dependent pathway of platelet activation in healthy overweight subjets. Plateletfree calcium concentration may be involved in platelet response to leptin stimulation via ObRb on platelet membrane. The stimulation of phospholipase C (PLC) in phospholipids membrane is an early step in cellular activation, including platelets that resulted in the hydrolysis of phosphatidylinositol 4,5 diphosphate. This, in turn, leads to the formation of 1,2-diacylglycerol (DAG) and inositol 1,4,5 triphosphate (IP3). DAG is known to stimulate protein kinase C (PKC) and IP3 is able to mobilize intracellular calcium for platelet activation.

\section{THE ASSOCIATION BETWEEN PLATELET ACTIVATION AND ATHEROSCLEROSIS IN OVERWEIGHT}

Overweight can be referred as a leptin resistance condition. Leptin is a product of adiponectin from $o b$ gene $^{14}$, that signals the energy stores level via receptor in central nervous system. Leptin regulatesactivity of the hypothalamic nuclei, responsible for appetite and energy homeostasis. This hormone is antioverweight, with its level decreasing during fasting and increasing after overfeeding in order to maintain energy status. Thus, leptin resistance in overweight subjects may signify the relationship between leptin concentration and overweight ${ }^{15}$. Multiple evidences have demonstrated that this hormone could engage in many pathophysiological pathways that could result in leptin resistance in different cells, arterial thrombosis formation ${ }^{16}$, platelet activation and aggregation ${ }^{17}$, arterial hypertension ${ }^{18}$ and vascular response to in- flammation ${ }^{19,20}$. Other studies have shown that leptin is a prognosticator of atherosclerosis, myocardial infarction, stroke and coronary artery episode which is independent of body fat ${ }^{21}$.

The overall ability of this hormone to increase human platelet activation has been suggested in $\mathrm{OB} / \mathrm{OB}$ mice and healthy control subjects ${ }^{11,21}$. However, Ozata et al. did not observe leptin on epinephrine, collagen and ADP platelet activation in both obese and overweight healthy subjects, and in leptin-deficient individuals $^{22}$. Therefore, the notion of presence of leptin receptor on platelet membrane, signaling the prothrombotic episode of leptin resistance is still controversial. However, the association between platelet activation in overweight/obesity with dyslipidemia and endothelial dysfunction, triggers human platelet activation and aggregation, thus further enhancing the risk of atherosclerosis events ${ }^{23}$. Furthermore, studies have shown that obesity triggers platelet activation via release of an inflammatory mediator that activates multiple internal signaling networks, includ- 
ing platelet miRNA ${ }^{24}$. The role of miRNA (miR) on leptin resistance has been demonstrated in several gene expression profiles. MiRNA plays a modulation role in different metabolites. Thus, the exact effect of platelet miRNA on leptin in hypothalamic center remains elusive. The up-regulation of miR-200b and miR-200a were observed in hypothalamus center of obese-deficient ob/ob mice, and down-regulation of miR-200b and miR-200a were reported after leptin treatment in the hypothalamus ${ }^{25}$. Reduced level of miR-200b and miR-200a in the hypothalamic center induced the expression of both insulin and leptin receptors that signal the reduction of fat deposit and further restored insulin function in the liver ${ }^{26}$. These miRNAs were present in activated platelets, suggesting that up regulation of miR-200a and miR-200b from activated platelets in overweight/obesity was altered (Table 1). Such alteration influenced leptin and insulin receptor signaling pathways in the hypothalamic nuclei ${ }^{25}$ which could serve as a target for therapeutic intervention in obesity/overweight individuals.

\section{PLATELET ACTIVATION AND PROTEIN SYNTHESIS}

Platelets are made up of three secretory granules: the $\alpha$-granules, lysosomes and dense granules ${ }^{27}$. The content of these granules is released into plasma after platelet activation, which may enhance and promote elevation levels of pro-atherogenic proteins. This includes growth factors (TGF- $\beta$, PDGF, bFGF and EGF), adhesion proteins (fibronectin, fibrinogen, Pselectin, thrombospondin, vWF, vitronectin, receptor complex glycoproteinIba-V-IX (GPIba-V-IX,), collagen receptor GP VI and GPIIb-IIIa), epithelial neutrophil activating protein 78 (ENA-78), chemokines CXC chemokine ligand 4 (CXCL4), RANTES (CCL5), platelet factor 4 (PF4), coagulation factors (factor V, XI, XIII), $\alpha 2$-antiplasmin, PAI-1 (plasminogen activator inhibitor), TFPI (tissue factor pathway inhibitor), protein $S$, antithrombin, plasminogen, cytokine-like factors (CD40L, $\beta$-thromboglobulin and IL-1 $\beta$ ) and miRNA ${ }^{28}$ (Figure 2).

\section{REGULATORY AND B IOGENESIS OF PLATELET MIRNA}

MiRNAs are a short class of non-coding endogenous RNAs, that post-regulate gene expression transcriptionally via either translational mRNA degradation, or repression. MiRNAs play crucial roles in controlling biochemical functions and mechanisms of different types of cells, including cell differentiation, developmental timing, tumorigenesis, proliferation, apoptosis as well as thrombosis and platelet functions. Similarly, miRNA itself as a regulatory element, is coordinatively modulated by multifarious effectors when carrying out basic functions, such as miRNA editing, single-nucleotide polymorphism, circadian clock and methylation. Platelet miRNAs act together in order to fine-tune and regulate a wide variety of this molecules in form of mRNA in different cellular functions. Those include aggregation, cell adhesion, proliferation, activation, chemotaxis, coagulation, proteolysis and cell survival. During these events, the mRNA is synthesized from DNA transcription and further translated into protein. Certain specific regions of these mRNA molecules are not normally translated into proteins. These regions include the $5^{\prime}$ untranslated region (5' UTR), $5^{\prime}$ cap, poly-A tail and $3^{\prime}$ untranslated region (3' UTR). $3^{\prime}$ UTR often contains regulatory site that influences and regulates the posttranscriptional gene expression profiling ${ }^{29}$. Britton and Davidson, (1969) ${ }^{30}$ postulated that "activator" mRNA transcript may work to turn on and off genes as predicted by Watson-Crick base pairing to region, located within genes ${ }^{31}$. Three major forms of sRNAs regulation in plants and animals were identified, which include small interfering RNAs (siRNA), miRNAs (miRNA) and piwi-interacting RNAs (piRNA). Landry et al., $2009^{32}$ found, that the platelet miRNA was not usually translated into protein, but it regulated mRNA by annealing to the recognition site on 3' UTR of mRNA, coding gene sequence of 2-8 nucleotide, complementary to miRNA seed region ${ }^{33}$. This pairing was based on Watson-Crick nucleotide base pairing, such as miRNA-mRNA. The hybridization of these complexes does not require full complementary homology ${ }^{34}$ and complete homolog usually leads to degradation of a target mRNA, while partial pairing homology is a translational repression. Therefore, miRNA influences degradation to regulate mRNA by switching the functional gene transcript on and off, while translational repression of miRNA regulates the function of the protein expression ${ }^{34,35}$. This functional role of miRNA presumes a wide range of miRNA-mRNA interactions, following either convergent (many miRNA-Single targets), or divergent (single miRNA-many target mRNA) interaction. This results in robust pathways that regulate the synthesis of protein in a cell ${ }^{35}$.

Currently, the nature and extent of the involvement of platelet miRNAs in a non-(protein)-coding ribonucleic acids (RNAs) in physiology and pathological 


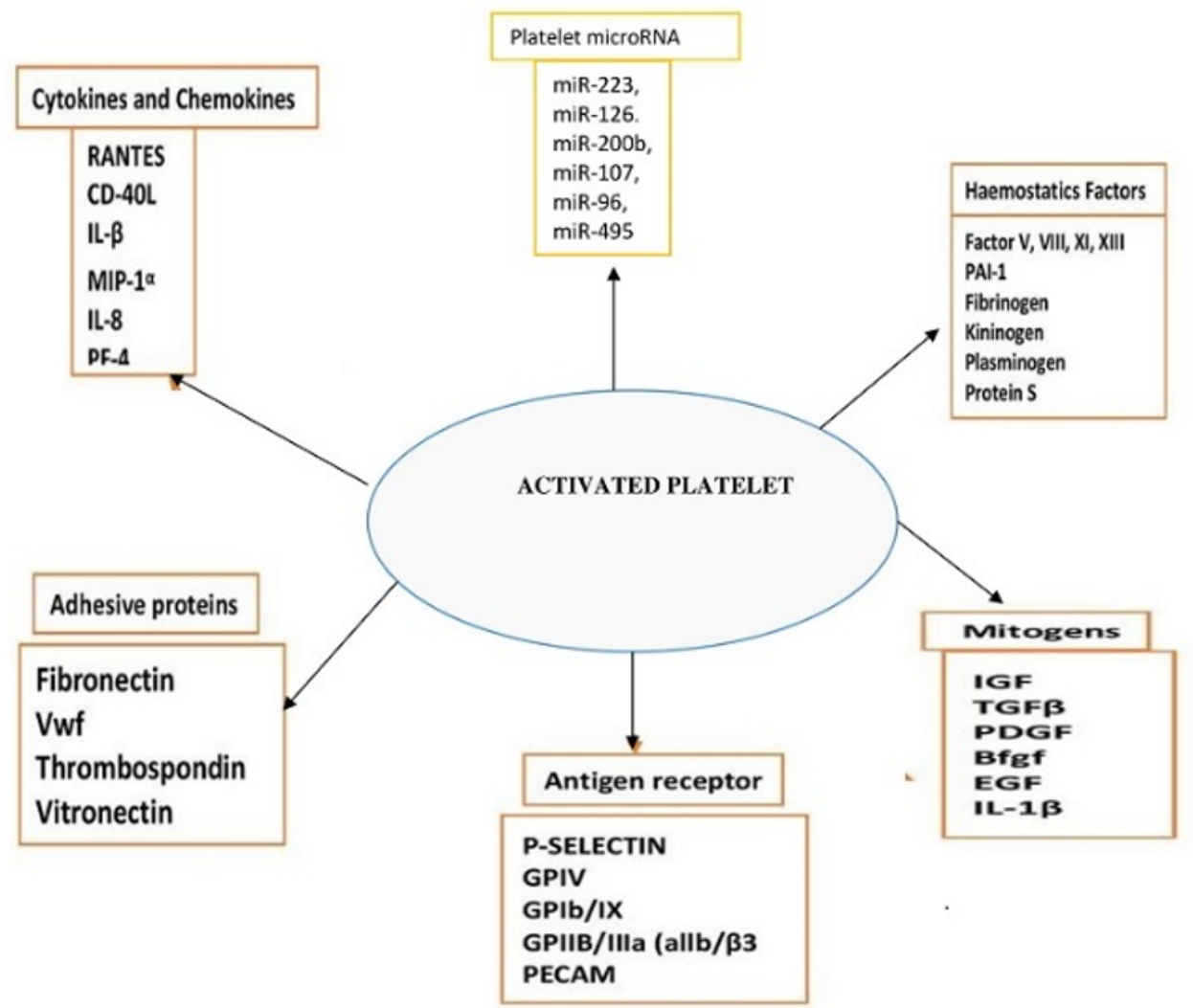

Figure 2: Activated platelet releases both activation and inflammation makers, including the platelet miRNA. Blood platelets are important for coagulation physiology and maintaining hemostatic balance, which is involved in various pathologies, such as thrombosis and atherosclerosis. Anucleated platelets are able to trigger protein synthesis via mRNA translation for blood platelets function and is regulated by miRNA molecules. Recent works postulated the possibility of using miRNAs as biomarkers for atherosclerosis and ischemic episodes.

processes (in both plant and animals) has become clearer $^{35}$. More than 280 miRNAs have been recognized and characterized from human nucleated platelets ${ }^{31,35}$. The miRNAs biosynthesis in biological systems is strictly regulated.

The biogenesis of platelet miRNAs began with transcription of the gene in non-coding region of miRNA using RNAs poly-III from the genome of megakaryocytes, harboring miRNA gene in either intergenic or intronic at promoter site. The first primary miRNA as a non-coding transcript is known as pri-miRNA, which acts upon by RNA poly III (called "Drosha"), that bounds to the microprocessor subunits DGCR8 (di-george syndrome critical region-8) to produce a small length hairpin called pre-miRNA stemloop with 80-110 nucleotides base in length. Exporting-5 assists the nuclear export of pre-miRNA into the cytoplasm $^{36}$. The presence of pre-miRNAs in the cellular cytoplasm is identified by ribonuclease (RNase) or
Dicer enzymes which is a part of transactivation response binding protein (TRBP) complex. The complex Dicer/TRBP cleaves the pre-miRNAs loop to release a short length of double stranded miRNA, such as miRNA/miRNA, ${ }^{\star}$ or duplex ${ }^{37}$. The duplex (such as miRNA/miRNA) are transported into the RNA Induced Silencing Complex (RISC) ${ }^{38,39}$ and Helicase enzymes are used to unwind the double stranded miRNA into a single 22 nucleotides base, which is released as matured miRNA. The $2^{\text {nd }}$ strand miRNA, known as passenger strand is thought to be digested by the RISC complex substrate. Argonauts (Ago) protein family will assemble in RISC and provide stability and protection to the mature miRNA strand against RNase enzymes activities and will further guide the matured miRNA to its target $3^{\prime}$-untranslated region (UTR) of mRNA transcripts ${ }^{40}$ (Figure 3 ). However, the inverse modulation of platelet miRNA profiling during adipose tissue development in overweight and 
obesity is important for understanding miRNA dysregulation in adipose tissue of both obese humans and mice. Such modulation enhances chronic inflammation observed in obesity subject with insulin resistance ${ }^{41}$. Thus, a single nucleotide base change of mature and pre-miRNA may drive the emerging of new miRNA by influencing the biological function of these cells ${ }^{40}$.

\section{PATHOLOGICAL ROLE OF PLATELET MIRNA IN CORONARY ARTERY DISEASE}

The mutations or single-nucleotide polymorphism (SNP) that occur in the biogenesis of both mRNA and miRNA can be classified as follows:

(1) Mutations, that affect biogenesis enzymes of miRNA, or the promoter region of mRNA.

(2) Mutations, that affect the 3' UTR region of the mRNA.

(3) Mutations that affect the miRNA seed region. ${ }^{42}$

\section{Mutation or SNP that affects miRNA bio- genesis enzymes}

SNP in the processing regions can be categorized as pri-miRNA, pre-miRNA, mature miRNA sequences and mRNA biogenesis machinery (promoter region). In fact, gene variations may influence either miRNA hairpin and biogenesis proteins, or enzymes in the processing accuracy ${ }^{43}$.

\section{Mutation in the miRNA seed region}

SNP in the seed region of miRNA may reduce the binding strength between miRNA and mRNA target sites, which will influence hundreds of gene expressions $^{44}$.

\section{Mutation in the mRNA 3' UTR-region}

Approximately 180,000 mutations or SNP found within the 3' UTR region mRNA were demonstrated with its corresponding mature miRNA 2,600 sequences. These were found in database sequence ${ }^{45}$. Mutations in the seed region of miRNA and 3' UTR region of mRNA are almost identical in terms of variations and regulation of miRNA-mRNA* complex, affecting functions and disease vulnerability ${ }^{42}$. However, further molecular mechanism underlying disease-associated with 3' UTR SNPs in mRNA still require further investigation ${ }^{46}$. For example, SNP meta-analysis of 8,120 patients and 8,364 controls identified four different SNPs in the following miRNAs (miRNA-149, miRNA-196a2, miRNA-499 and
miRNA-146a), which increased patients CAD vulnerability ${ }^{47}$. Other articles have demonstrated that miR146a was upregulated in $\mathrm{CAD}^{47,48}$ due to the change of $\mathrm{G}$ to $\mathrm{C}$ in pre-miRNA. That affected the expression of mature miRNA-146a in CAD patients ${ }^{49}$. That finding was confirmed by Wang et al. and showed, that $C$ allele was greater than $G$ allele in gene that predisposed individuals to $\mathrm{CAD}^{50,51}$. However, in type 2 diabetes patients with ischemic stroke, the miR146a was downregulated (Table 1) ${ }^{52}$. Other abundant miRNAs found in platelets miRNA were miR-223 and miR-126. In addition, miR-223, miR-107, miR- 495, miR-96 and miR-200b were actively involved in various platelet functions, such as platelet release, adhesion and aggregation, ${ }^{53}$ as summarized in Table 2.

\section{MIRNA AS BIOMARKERS}

The fact of discovery of miRNA as a stable molecule in plasma and serum is surprising despite the level of RNase enzymes activities ${ }^{54}$. The expression of miRNA in tissue, or organ-specific, and its release into the plasma in response to tissue injury is considered to be a potential biomarker for different diseases ${ }^{55}$. The hypothesis that miRNA in blood cells could be used as diagnostic parameter in different diseases was first postulated by Mitchell et al. . He showed, that miRNA remained highly stable in both plasma and serum even after prolonged storage at room temperature, or repeated cycles of freezing and thawing. For example, tumor-derived miRNA could easily be identified in plasma sample from cancer patient with standard laboratory procedure ${ }^{54,56,57}$. The diagnostic role of circulating miRNA has been evaluated not only in cancer, but also in other clinical disorders, such as hepatic disease ${ }^{58}$, heart failure ${ }^{59}$ and diabetes ${ }^{60}$. Few studies have claimed platelets in obesity and overweight healthy individuals as the culprit factor, responsible for coronary artery disease ${ }^{61}$. The application of specific platelet miRNAs as markers for platelet activation will be a marginal milestone in the history of this diet-related disorder.

\section{PLATELET- MIRNA IN ENDOTHELIAL AND VASCULAR SMOOTH MUSCLE (VSCM) CELLS IN CORONARY ARTERY DISEASE (CAD)}

Large scale studies, presented by Nagalla et al. and Landry et al. found, that thirty different platelet miRNAs modulate platelet and endothelial angiogenesis (angio-miRs) ${ }^{32,35}$. These miRNAs, (miR-21, miR-200, miR-210 and miR-126), are well known 


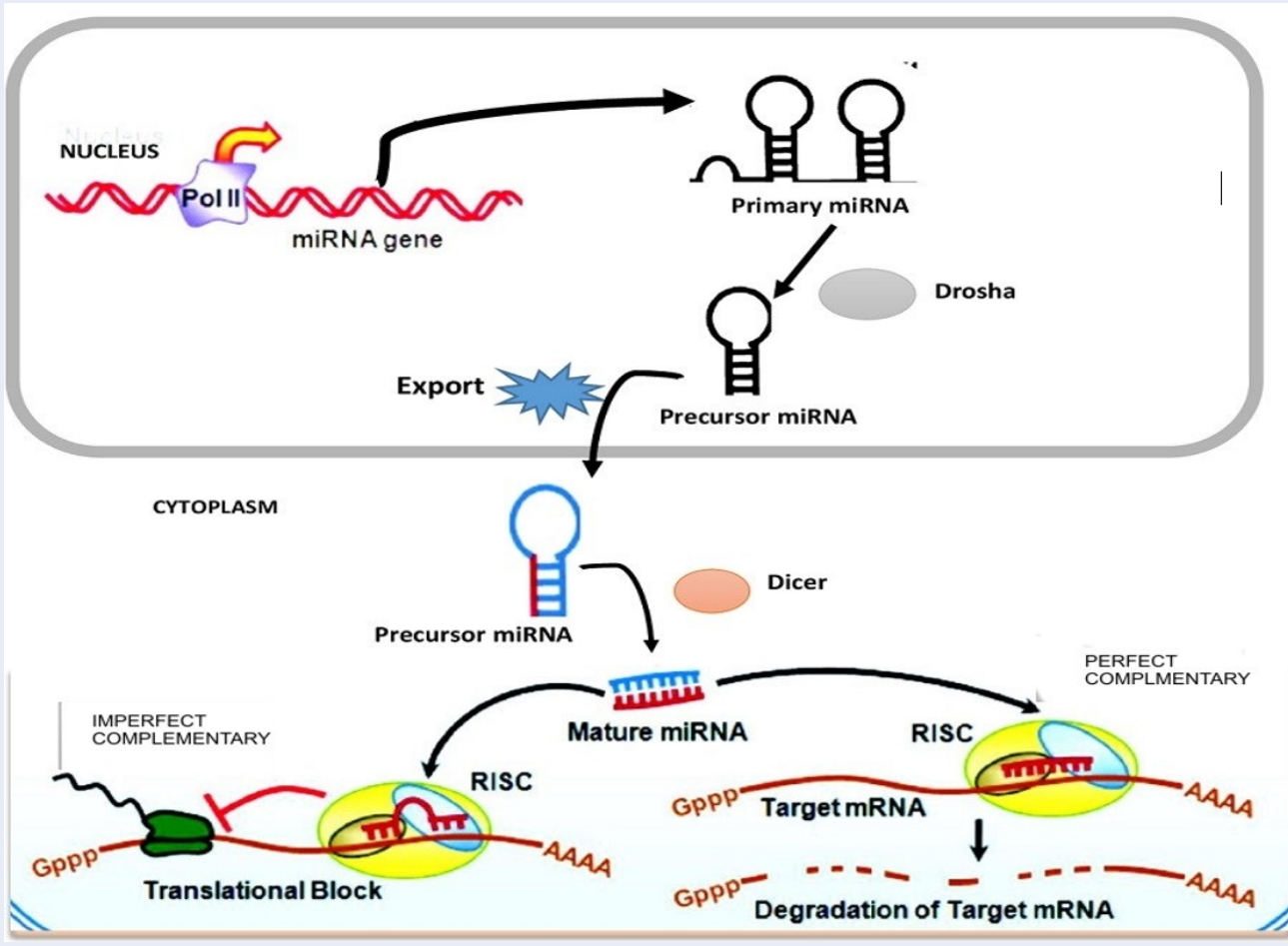

Figure 3: Mechanism of platelet miRNA to induce repression of mRNA. Production pri-miRNA* from miRNA genes is processed by RNase-II/III and the pri-miRNA form is cleaved by Drosha-DGCR8 complex to produce premiRNA* in the nucleus. Pre-miRNA* is exported by exportin-5 from the nucleolus to the cytoplasm. The premiRNA* in the cytoplasm is further digested by another enzme called RNase-Dicer complex with TRBP that catalyzed the pre-miRNA* hairpin to mature miRNA duplex. Matured miRNA strand is transported into RISC in assemble of argonaute-2 (Ago2) proteins to guide the silencing of target mRNA to fully complementary matched for degradation and partially complementary matched for repression. This figure is adopted and modified DOI: 10.5772/ intechopen.81847.

to play critical roles in the vessel and capillary formation. The regulation of angiogenesis by miRNA in the endothelial cell was confirmed, using Dicerknockdown mice experiment, demonstrating the essential role of Dicer in miRNA biogenesis ${ }^{62,63}$. Furthermore, Dicer gene deletion was shown to cause early death of mice during the embryonic stage, due to impaired angiogenesis ${ }^{64}$. In addition, Dicer knockdown of vascular smooth muscle cells VSMC specific caused the late embryonic death due to internal bleeding ${ }^{65}$, suggesting that platelet miRNA was an integral part of vascular development. Therefore, clusters of miR-221 and miR-222 are the most abundant and well distributed miRNAs across these three cells(platelet, endothelial and VSMC) ${ }^{66,67}$. Both miR221 and miR-222 function as pro-inflammatory inhibitor of angiotensin II and reversed leucocytes adhesion (in vivo and in vitro) ${ }^{68}$, suggesting a possible role of these miRNA clusters in CAD dysregulation. The endothelial-enriched miR-92a has been proposed as a possible therapeutic target after treatment with anti-miR-92a oligonucleotide.Such treatment improved the formation of blood vessel and recovery of cardiovascular disorder in acute myocardial infarction in mice ${ }^{67}$. MiR-143/145 is the most abundant miRNA found in VSCM and is well characterized as part of the same bi-cistronic cluster. These miRNAs target multiple mRNAs to influence VSCM differentiation and simultaneously reduce proliferation ${ }^{68}$. The delivery of miR-145 by lentiviral in endothelial and VSCM inhibits monocyte/macrophages recruitment and infiltration, thus reducing inflammation and limiting plaque formation. These results suggest a new therapeutic target in order to decrease atherosclerotic progression and increase plaque atrial stability ${ }^{69}$. 


\section{ROLE OF PLATELET MIRNA AS A MARKER IN CORONARY ARTERY DISEASE (CAD)}

Previous reports showed that more than 80 different diseases were associated with dysregulation, or mutation in miRNAs ${ }^{70}$. The mechanisms of platelet activation in various thrombotic diseases were well established $^{71}$. The accurate etiology of miRNA in activated platelet in overweight and obesity is not clear, but obesity is always a risk factor for atherothrombotic episodes $^{71}$. Landry et al. 2009 demonstrated that the platelets and megakaryocyte miRNAs had 219 different types of miRNA in platelet expression patterns and profiles ${ }^{72}$. The authors observed three most abundant miRNAs in human platelets; miR-19a, let-7c, and miR-223. Binding of miRNA-223 to 3' UTR region of P2Y12 mRNA receptor in HEK293 cell line repressed P2Y12 gene and decreased the activities of both platelet and megakaryocyte. However, dysregulation of miRNA-233 was observed in hyperreactive platelet, leading to overexpression of miRNA$223^{73}$. Thus, miR-223, miR-197 and miR-126 were involved in platelet hyperreactive and endovascular inflammation, stretching the application of these miRNAs as predictive biomarkers for diagnosis of CAD (Table 1) ${ }^{73}$.

\section{CAD, CORONARY ARTERY DISEASE; QRT-PCR, REAL-TIME QUANTITATIVE REVERSE TRANSCRIPTION PCR}

In 2013, Osman and Fälker discovered 281 transcripts, of which 228 were mature miRNAs and 53 were pre-miRNAs. Six miRNAs: miR-339-3 p, miR15 a, miR-365, miR-495, miR-361-3 p and miR-98, were upregulated, or downregulated in hyperreactive platelets $^{28}$. The level of expression pattern, or characteristic of miRNAs in platelets were associated with a procoagulant (such as thrombin stimulation). $\mathrm{Na}$ galla et al., 2011 demonstrated that there were 284 miRNA transcripts in human platelets, by which 74 were differentially expressed, based on the platelet reactivity $^{35}$. Seven miRNA expression profiles (miR320b, miR-190, miR-320d, miR-19b, miR-34b, miR$320 \mathrm{c}$ and miR-320a) were shown to have a strong relationship with the degree of platelet response to adrenaline ${ }^{35}$. In fact, the most abundant expressed platelets miRNA is miR-223, followed by miR-126 ${ }^{57}$. Others were identified as miR-200b, miR-107, miR-96 and miR- $495^{53}$. All of these miRNAs were involved in platelet hyperreactivity (such as platelet activation, adhesion and aggregation, as summarized in Table 2). 


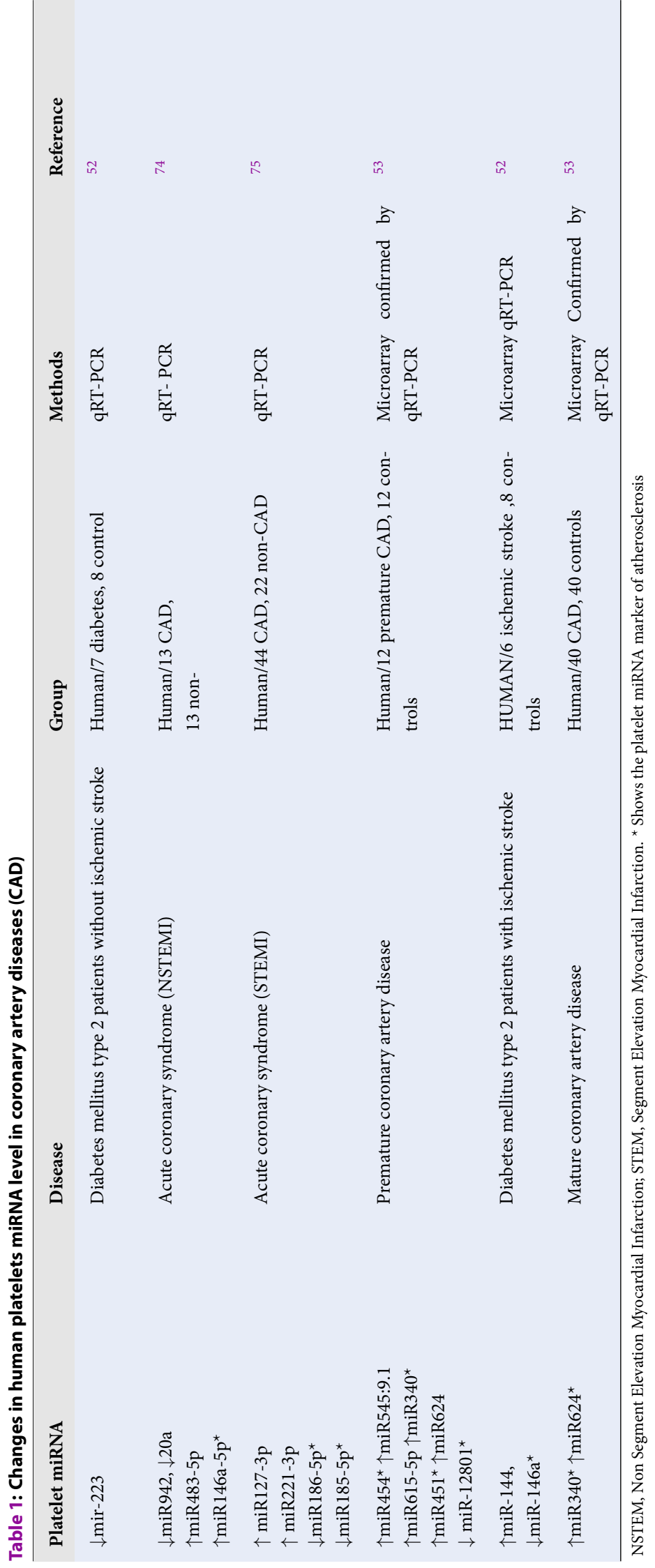


Table 2: Pathophysiology of platelet miRNA in platelet activation

\begin{tabular}{|c|c|c|c|c|c|c|}
\hline & Platelet miRNA & $\begin{array}{l}\text { Target protein } \\
\text { (mRNA) }\end{array}$ & Function & Pathophysiology & Implication & Ref \\
\hline 1. & miRNA-223 & $\begin{array}{l}\text { P2Y12 receptor } \\
\text { for } A D P\end{array}$ & Regulate platelet Hyperreactive & $\begin{array}{l}\text { miRNA-233: Dysregulation of } \\
\text { miRNA-233 will results in hyper- } \\
\text { reactive platelet, leading to upreg- } \\
\text { ulation miRNA- } 223 \uparrow\end{array}$ & $\begin{array}{l}\text { miR-223 and miR-197 are } \\
\text { platelet activation miRNA } \\
\text { involved in vascular inflam- } \\
\text { mation and have been shown } \\
\text { as markers in the diagnosis of } \\
\text { CAD. }\end{array}$ & 73,76 \\
\hline 2. & miRNA-200b & cAMP-dependent PKA & Keep platelet in hyporeactive state & $\begin{array}{l}\text { miRNA-200b: Dysregulation in } \\
\text { obesity/overweight subjects lead } \\
\text { to release of plate } \alpha \text { lpha- and } \\
\text { dense granules that harbor in- } \\
\text { flammatory molecules in platelet. } \\
\text { miRNA-200b inhibits endothelial } \\
\text { angiogenesis upregulates } \uparrow\end{array}$ & $\begin{array}{l}\text { Overexpression of miR- } 200 \mathrm{~b} \text { in } \\
\text { platelet activation may be used } \\
\text { as a diagnostic maker of CAD }\end{array}$ & 77,78 \\
\hline 3 & miR-107 & CLOCK/Bmal1 & $\begin{array}{l}\text { vWF gene is regulated by } \\
\text { CLOCK/Bmall complex in nor- } \\
\text { mal physiological state }\end{array}$ & $\begin{array}{l}\text { miRNA-107: Dysregulation } \\
\text { increased the plasma level of } \\
\operatorname{vWF} \uparrow\end{array}$ & $\begin{array}{l}\text { Association with a prothrom- } \\
\text { botic state that promote CAD }\end{array}$ & 79 \\
\hline 4. & $\begin{array}{l}\text { Member of miR- } \\
17-92 \text { cluster } \\
(\text { miR-17) }\end{array}$ & Fibronectin & $\begin{array}{l}\text { Fibronectin aids in the formation of } \\
\text { stable arterial thrombi at the site of en- } \\
\text { dothelial } \\
\text { injury }\end{array}$ & $\begin{array}{l}\text { Inhibition of fibronectin by miR- } \\
17 \text { leads to impeded platelet coag- } \\
\text { ulation and wound healing and is } \\
\text { downregulated } \downarrow\end{array}$ & $\begin{array}{l}\text { miR-17-92 and its family were } \\
\text { dysregulated in CAD }\end{array}$ & 80,81 \\
\hline 5 & $\begin{array}{l}\mathrm{miR} 29 \mathrm{a}^{\star} / \mathrm{miR}- \\
409-3 \mathrm{p}^{\star} \text { and } \\
\text { fibrinogen }\end{array}$ & $\begin{array}{l}\text { FGA, FGB, } \\
\text { and FGG) }\end{array}$ & $\begin{array}{l}\text { Fibrinogen functions as hemostatic } \\
\text { plug formation, }\end{array}$ & $\begin{array}{l}\text { miR-29 reduce the level of mRNA } \\
\text { genes such as FGG, FGB and } \\
\text { FGA. Dysregulation of these } \\
\text { miRNAs has been linked with } \\
\text { cardiac fibrosis } \downarrow\end{array}$ & $\begin{array}{l}\text { miR-29 family are grouped } \\
\text { with MI-regulated member }\end{array}$ & 82,83 \\
\hline
\end{tabular}




\begin{tabular}{|c|c|c|c|c|c|c|}
\hline \multicolumn{7}{|c|}{ Table 2 continued } \\
\hline & Platelet miRNA & $\begin{array}{l}\text { Target protein } \\
\text { (mRNA) }\end{array}$ & Function & Pathophysiology & Implication & Ref \\
\hline 6. & $\begin{array}{l}\text { miR-96 and } \\
\text { miR-15 }\end{array}$ & VAMP8 & $\begin{array}{l}\text { miR-96 and miR-15 regulate VAMP8. } \\
\text { VAMP8 aids in platelet activation, } \\
\text { secretion of } \alpha \text {-granules and platelet } \\
\text { function. }\end{array}$ & $\begin{array}{l}\text { SNPs in the } 3 \text { untranslated region } \\
\text { ( UTR) } \\
\text { of VAMP8 mRNA resulted in } \\
\text { VMP8 mRNA dysregulation and } \\
\text { is upregulated } \uparrow\end{array}$ & $\begin{array}{l}\text { The consequence } \\
\text { of reduced VAMP8 mRNA } \\
\text { control is due to an excess of } \\
\text { VAMP8 } \\
\text { in platelets and higher platelet } \\
\text { reactivity, leading to increased } \\
\text { risk of myocardial infarction }\end{array}$ & 84 \\
\hline 8 & $\begin{array}{l}\text { miR-126 present } \\
\text { in both platelet } \\
\text { and endothelial } \\
\text { cell }\end{array}$ & VCAM-1 & $\begin{array}{l}\text { The target of miRNA-126 is VCAM } \\
\text { mRNA, and the suppression of VCAM } \\
\text { leads to decreasing infiltration of leu- } \\
\text { cocytes into the vascular endothelial } \\
\text { cell }\end{array}$ & $\begin{array}{l}\text { Mutation of miR-126 resulted } \\
\text { in the expression of TNF- } \alpha \text { that } \\
\text { stimulate VCAM- } 1 \text { expression } \\
\text { and increase leukocyte adherence } \\
\text { to endothelial } \downarrow\end{array}$ & Promotes CAD & 86,87 \\
\hline 9 & miR-210. & $\begin{array}{l}\text { ephrina3 receptor (efna3) } \\
\text { and } \\
\text { Tyrosine protein and } \\
\text { Phosphatase(ptp1b) }\end{array}$ & $\begin{array}{l}\text { The repression of the two molecules } \\
\text { (ptp1b and efna3) by miRNA- } 210 \text { en- } \\
\text { hances angiogenic property and en- } \\
\text { dothelial angiogenesis }\end{array}$ & $\begin{array}{l}\text { Mutation lead to downregulation } \\
\text { of miR-210 }\end{array}$ & Angiogenesis after MI & 88 \\
\hline 10 & $\mathrm{miR}-21$ & $\begin{array}{l}\text { Rho kinase, SPROYTY2, } \\
\text { RhoB, } \\
\text { BMPRII, SOD2 and PTEN }\end{array}$ & $\begin{array}{l}\text { All possess anti-angiogenic functions. } \\
\text {. }\end{array}$ & 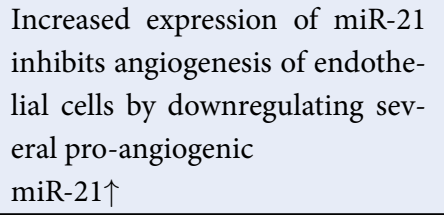 & $\begin{array}{l}\text { Atherosclerosis, CAD, apopto- } \\
\text { sis and neoangiogenes }\end{array}$ & $89-91$ \\
\hline
\end{tabular}

miRNA (miR), mRNA (messenger RNA), $\uparrow$ : upregulation, $\downarrow$ : down-regulation, CAD: Coronary ArteryDisease 
Plé and colleagues in 2012 detected more than 492 different mature miRNA transcripts in active platelets $^{74,75,92}$. A total of 15 novel miRNAs were identified from human platelet: miR-103, miR-140, miR-24, miR-185, miR-223, miR-23, miR-320, miR25, miR-21, miR-26, miR-191, miR-423, miR-101, miR-199 and let- $7^{86}$. This finding suggested a possible relationship between the platelet activation and the miRNA modification, which may an induce agonist-specific platelet function.

Jeanine et al., 2014 also reported the expression profile of platelet miRNA in patients with acute coronary syndrome after a series of diagnostic investigations. In blood sample of STEMI patients, miR185-5p and miR186-5p were downregulated, while miR221$3 p$ and miR127-3p were upregulated in platelets. On the other hand, in blood samples of NSTEMI patients, miR942 and miR20a-5p were downregulated, whereas miR146a-5p and miR483-5p were upregulated in platelets (Table 2) ${ }^{74}$. Thus, in body circulation, the pathophysiology of platelet miRNA can exhibit clear characteristic differences of expression profiling in various platelet disorders. This condition however is dangerous if urgent measure is not taken, since the risk of heart failure (HF) in such case is eminent. Patients with systolic heart failure were found to have different platelet miRNA expression profiles, as compared to control subjects ${ }^{56}$. Platelets miRNA150 expression level decreased more than three-fold in blood platelets of patients with heart failure, secondary to atrial fibrillation (Table 2) ${ }^{75}$.

In addition, the study, conducted by Duan et al., 2014 showed, that the expression of platelet miRNA-223 and miRNA-146a in patients with ischemic stroke and diabetes mellitus was significantly higher, compared to healthy donors. The expression level of these two platelet miRNAs was suggested to correlate with platelet activation (Table 2) ${ }^{52}$.

\section{CONCLUSION}

The gene expression and bioinformatic analysis procedures have become the state-of-the-art methods for diagnosing a number of human diseases. Several studies have reported different miRNA expression profiles in platelets. The application of these miRNAs for diagnostic purpose in overweight healthy subjects will be a milestone in the history of treatment of this diet-related disorder. Six notable candidates of platelet miRNAs have been discovered and proposed for diagnostic accuracy in CAD upregulation: $\uparrow$ miR483-5 $\mathrm{p}^{*} \uparrow \operatorname{miR} 146 \mathrm{a}-5 \mathrm{p}^{*} \uparrow \mathrm{miR} 340^{*} \uparrow \mathrm{miR} 624^{*}$, $\uparrow \mathrm{miR} 451^{\star}$ and $\uparrow \mathrm{miR} 454^{\star}$. Current modern diagnostic laboratory method for identification of coronary obstruction is still in its early stage. Nevertheless, current molecular medicine and diagnostic methods are capable to identify if an individual is predisposed to the illness. Platelet miRNA expression profile detection is associated with platelet hyperactivity and may serve as an important marker for prevention of coronary artery disease (CAD) in human overweight/obesity.

\section{ABBREVIATIONS}

ADP: Adenosine diphosphate

BFGF: Basic Fibroblast Growth Factor

CAD: coronary artery disease

cAMP: cyclic adenosine monophosphate

CCL5: RANTES

CD40L: CD40 Ligand

CHD: Coronary heart disease

CVDs: cardiovascular disorders

CXC: Chemokines

CXCL4: Chemokine ligand 4

DAG: 1,2-diacylglycerol

DGCR 8: di-george syndrome critical region-8

DNA: Deoxyribonucleic Acid

EGF: Epidermal Growth Factor

ENA: 78- epithelial neutrophil activating protein 78

IL-1 $\beta$ : interleukin $-1 \beta$

IP3: inositol 1,4,5 triphosphate.

miRNA: microRNA

mRNA: messenger RNA

NSTEM: Non Segment Elevation Myocardial Infarction;

ObRb: Leptin receptor

PAI-1: Plasminogen Activator Inhibitor,

PDGF: Platelet-derived growth factor

PF4: platelet factor 4

piRNA: piwi-interacting RNAs

PKC: protein kinase $\mathrm{C}$

PLC: phospholipase C

RISC: RNA In-duced Silencing Complex

siRNA: small interfering RNAs

SNP: single-nucleotide polymorphism

STEM: Segment Elevation Myocardial Infarction

TFPI: tissue factor pathway inhibitor,

TGF- $\beta$ : Transforming growth factor beta

TRBP: Transactivation Response Binding Protein

UTR: untranslated region

VAMP8: Vesicle-associated Membrane Protein 8

VCAM-1: Vascular Cell Adhesion Molecules-1

VSMC: Vascular Smooth Muscle Cells

vWF: von willbrand factor

WHO: World Health Organization 


\section{COMPETING INTERESTS}

The author declares no conflict of interest regarding the article for publication.

\section{AUTHORS' CONTRIBUTIONS}

Sabariah Md Noor: initiate the conception and technicality; Azrina Azlan, and Loh Su Peng: guide the article publication along with flow of idea and amending the figure respectively; Yakubu Abdulrahman: do the written and revision of the paper.

\section{ACKNOWLEDGMENTS}

This work was supported by the Geran Putra IPS 957600 (Putra Grant Initiative) from Universiti Putra Malaysia (UPM).

\section{REFERENCES}

1. Purkayastha $S$, Cai $D$. Neuroinflammatory basis of metabolic syndrome. Mol Metab. 2013;2(4):356-63. PMID: 24327952. Available from: 10.1016/j.molmet.2013.09.005.

2. Heap GA, van Heel DA. The genetics of chronic inflammatory diseases. Hum Mol Genet. 2009;18:101-6. PMID: 19297396. Available from: $10.1093 / \mathrm{hmg} / \mathrm{ddp} 001$.

3. Update OEO. Obesity Update 2017. Diabetologe (Heidelb). 2017;13(5):331-41. Available from: 10.1007/s11428017-0241-7.

4. Mazzoccoli G, Copetti M, Dagostino MP, Grilli M, Fontana A Pellegrini $F$, et al. Epicardial adipose tissue and idiopathic deep venous thrombosis: an association study. Atherosclerosis. 2012;223(2):378-83. PMID: 22748278. Available from: 10.1016/j.atherosclerosis.2012.05.033.

5. Vayá A, Martínez-Triguero ML, España F, Todolí JA, Bonet $E_{\text {, }}$ Corella D. The metabolic syndrome and its individual components: its association with venous thromboembolism in a Mediterranean population. Metab Syndr Relat Disord. 2011;9(3):197-201. PMID: 21352080. Available from: 10.1089/ met.2010.0117.

6. Werner N, Nickenig G. From fat fighter to risk factor: the zigzag trek of leptin. Arterioscler Thromb Vasc Biol. 2004;24(1):79. PMID: 14707035. Available from: 10.1161/01.ATV. 0000110908.43721.ad.

7. Sader S, Nian M, Liu P. Leptin: a novel link between obesity, diabetes, cardiovascular risk, and ventricular hypertrophy. Circulation. 2003;108(6):644-6. PMID: 12912793. Available from: 10.1161/01.CIR.0000081427.01306.7D.

8. Yang R, Barouch LA. Leptin signaling and obesity: cardiovascular consequences. Circ Res. 2007;101(6):545-59. PMID: 17872473. Available from: 10.1161/CIRCRESAHA.107. 156596.

9. Wallace AM, McMahon AD, Packard CJ, Kelly A, Shepherd J, Gaw A, et al. Plasma leptin and the risk of cardiovascular disease in the west of Scotland coronary prevention study (WOSCOPS). Circulation. 2001;104(25):3052-6. PMID: 11748099. Available from: 10.1161/hc5001.101061.

10. Nakata M, Yada T, Soejima N, Maruyama I. Leptin promotes aggregation of human platelets via the long form of its receptor. Diabetes. 1999;48(2):426-9. PMID: 10334326. Available from: $10.2337 /$ diabetes.48.2.426.

11. Konstantinides S, Schäfer K, Koschnick S, Loskutoff DJ. Leptindependent platelet aggregation and arterial thrombosis suggests a mechanism for atherothrombotic disease in obesity. J Clin Invest. 2001;108(10):1533-40. PMID: 11714745. Available from: 10.1172/JCI13143.

12. Mitchell AJ, Gray WD, Hayek SS, Ko YA, Thomas S, Rooney $\mathrm{K}$, et al. Platelets confound the measurement of extracel- lular miRNA in archived plasma. Sci Rep. 2016;6(September):32651. PMID: 27623086. Available from: 10.1038/ srep32651.

13. Edelstein LC, Nagalla S, Bray PF. MicroRNAs in Platelet Production and Activation. MicroRNAs Med. 2013;2013:101-116. Available from: 10.1002/9781118300312.ch7.

14. Stern JH, Rutkowski JM, Scherer PE. Adiponectin, Leptin, and Fatty Acids in the Maintenance of Metabolic Homeostasis through Adipose Tissue Crosstalk. Cell Metab. 2016;23(5):770-84. PMID: 27166942. Available from: 10.1016/ j.cmet.2016.04.011.

15. Jr MG, Leibel RL, Seeley RJ, Schwartz MW. Obesity and Leptin Resistance: Distinguishing Cause from Effect. Trends Endocrinol Metab. 2011;21:643-51. Available from: 10.1016/j. tem.2010.08.002.Obesity.

16. Mantzoros CS, Magkos F, Brinkoetter M, Sienkiewicz E, Dardeno TA, Kim SY, et al. Leptin in human physiology and pathophysiology. Am J Physiol Endocrinol Metab. 2011;301(4):56784. PMID: 21791620. Available from: 10.1152/ajpendo.00315 2011.

17. Elbatarny HS, Maurice DH. Leptin-mediated activation of human platelets: involvement of a leptin receptor and phosphodiesterase 3A-containing cellular signaling complex. Am J Physiol Endocrinol Metab. 2005;289(4):695-702. PMID: 15886225. Available from: 10.1152/ajpendo.00125.2005.

18. Bełtowski J. Role of leptin in blood pressure regulation and arterial hypertension. J Hypertens. 2006;24(5):789-801. PMID: 16612235. Available from: 10.1097/01.hjh.0000222743.06584. 66.

19. Paz-Filho G, Mastronardi C, Franco CB, Wang KB, Wong ML, Licinio J. Leptin: molecular mechanisms, systemic proinflammatory effects, and clinical implications. Arq Bras Endocrinol Metabol. 2012;56(9):597-607. PMID: 23329181. Available from: 10.1590/S0004-27302012000900001.

20. Allman M, Wallace M, Gaskin L, Rivera CA. Leptin induces an inflammatory phenotype in lean Wistar rats. Mediators Inflamm. 2009;2009:738620. PMID: 20150963. Available from: $10.1155 / 2009 / 738620$.

21. Chen TH, Lee CJ, Wang JH, Hsu BG. High Serum Leptin Level is Associated with Peripheral Artery Disease in Geriatric Individuals. Int J Gerontol. 2018;12(3):191-5. Available from: 10.1016/j.ijge.2018.02.001.

22. Ozata M, Avcu F, Durmus O, Yilmaz I, Ozdemir IC, Yalcin A. Leptin does not play a major role in platelet aggregation in obesity and leptin deficiency. Obes Res. 2001;9(10):627-30. PMID: 11595779. Available from: 10.1038/oby.2001.82.

23. Mao X, Ait-Aissa K, Lagrange J, Youcef G, Louis H. Hypertension, hypercoagulability and the metabolic syndrome: a cluster of risk factors for cardiovascular disease. Biomed Mater Eng. 2012;22(1-3):35-48. PMID: 22766701. Available from: 10.3233/BME-2012-0688.

24. Xia L, Zeng Z, Tang WH. The Role of Platelet Microparticle Associated microRNAs in Cellular Crosstalk. Front Cardiovasc Med. 2018;5:29. Available from: 10.3389/fcvm.2018.00029.

25. Dou L, Zhao T, Wang L, Huang X, Jiao J, Gao D, et al. miR-200s contribute to interleukin-6 (IL-6)-induced insulin resistance in hepatocytes. J Biol Chem. 2013;288(31):22596-606. PMID: 23798681. Available from: 10.1074/jbc.M112.423145.

26. Benoit C, Ould-Hamouda H, Crepin D, Gertler A, Amar L, Taouis M. Early leptin blockade predisposes fat-fed rats to overweight and modifies hypothalamic microRNAs. J Endocrinol. 2013;218(1):35-47. PMID: 23576026. Available from: 10.1530/ JOE-12-0561.

27. Sharda A, Flaumenhaft R. The life cycle of platelet granules. F1000 Res. 2018;7(0):236. PMID: 29560259. Available from: 10.12688/f1000research.13283.1.

28. Bijak M, Saluk J, Ponczek MB, Nowak P, Wachowicz B. The synthesis of proteins in unnucleated blood platelets. Postepy Hig Med Dosw. 2013;506:672-679. PMID: 24018431. Available from: http://www.phmd.pl/fulltxt.php?ICID $=1059587$.

29. Patil VS, Zhou R, Rana TM. Gene regulation by non-coding RNAs. Crit Rev Biochem Mol Biol. 2014;49(1):16-32. PMID: 
24164576. Available from: 10.3109/10409238.2013.844092.

30. Britten RJ, Davidson EH, Dike S. Gene Regulation for Higher Cells: A Theory. Science. 1969;165(3891):349-357. Available from: 10.1126/science.165.3891.349.

31. Ui-Tei K, Naito Y, Nishi K, Juni A, Saigo K. Thermodynamic stability and Watson-Crick base pairing in the seed duplex are major determinants of the efficiency of the siRNA-based offtarget effect. Nucleic Acids Res. 2008;36(22):7100-9. PMID: 18988625. Available from: $10.1093 / \mathrm{nar} / \mathrm{gkn} 902$.

32. Landry P, Plante I, Ouellet DL, Perron MP, Rousseau G, Provost P. Existence of a microRNA pathway in anucleate platelets. Nat Struct Mol Biol. 2009;16(9):961-6. PMID: 19668211. Available from: $10.1038 / \mathrm{nsmb} .1651$.

33. Small EM, Olson EN. Pervasive roles of microRNAs in cardiovascular biology. Nature. 2011;469(7330):336-42. PMID: 21248840. Available from: 10.1038/nature09783.

34. Bartel DP. MicroRNAs: target recognition and regulatory functions. Cell. 2009;136(2):215-33. PMID: 19167326. Available from: 10.1016/j.cell.2009.01.002.

35. Nagalla S, Shaw C, Kong X, Kondkar AA, Edelstein LC, Ma L, et al. Platelet microRNA-mRNA coexpression profiles correlate with platelet reactivity. Blood. 2011;117(19):5189-97. PMID 21415270. Available from: 10.1182/blood-2010-09-299719.

36. Lund E, Güttinger S, Calado A, Dahlberg JE, Kutay U. Nuclear export of microRNA precursors. Science. 2004;303(5654):9598.

37. Zamore PD, Tuschl T, Sharp PA, Bartel DP, Phillip D. DoubleStranded RNA Directs the ATP-Dependent Cleavage of mRNA at 21 to 23 Nucleotide Intervals. Zamore Thomas Tuschl. 2000;101:25-33. Available from: 10.1016/S0092-8674(00) 80620-0.

38. Preall JB, He Z, Gorra JM, Sontheimer EJ. Short interfering RNA strand selection is independent of dsRNA processing polarity during RNAi in Drosophila. Curr Biol. 2006;16(5):530-5. PMID: 16527750. Available from: 10.1016/j.cub.2006.01.061.

39. Siomi $\mathrm{H}$, Siomi $\mathrm{MC}$. On the road to reading the RNAinterference code. Nature. 2009;457(7228):396-404. PMID: 19158785. Available from: 10.1038/nature07754.

40. Gregory RI, Chendrimada TP, Cooch N, Shiekhattar R. Human RISC couples microRNA biogenesis and posttranscriptional gene silencing. Cell. 2005;123(4):631-40. PMID: 16271387. Available from: 10.1016/j.cell.2005.10.022.

41. Xie H, Sun L, Lodish HF. Targeting microRNAs in obesity. Expert Opin Ther Targets. 2009;13(10):1227-38. PMID: 19650761. Available from: 10.1517/14728220903190707.

42. Moszyńska A, Gebert M, Collawn JF, Bartoszewski R. SNPs in microRNA target sites and their potential role in human disease. Open Biol. 2017;7(4):170019. PMID: 28381629. Available from: 10.1098/rsob.170019.

43. Zhang W, Wang L, Zhou P, Song G, Shen M, Gan S, et al. Identification and analysis of genetic variations in pri-miRNAs expressed specifically or at a high level in sheep skeletal muscle. PLoS One. 2015;10(2):e0117327. PMID: 25699993. Available from: 10.1371/journal.pone.0117327.

44. Króliczewski J, Sobolewska A, Lejnowski D, Collawn JF, Bartoszewski R. microRNA single polynucleotide polymorphism influences on microRNA biogenesis and mRNA target specificity. Gene. 2018;640:66-72. PMID: 29032146. Available from: 10.1016/j.gene.2017.10.021.

45. Schwerk J, Savan R. Translating the Untranslated Region. J Immunol. 2015;195(7):2963-71. PMID: 26386038. Available from: 10.4049/jimmunol.1500756.

46. Vaishnavi V, Manikandan M, Munirajan AK. Mining the 3of autism-implicated genes for SNPs perturbing microRNA regulation. Genomics Proteomics Bioinformatics. 2014;12(2):92104. PMID: 24747189. Available from: 10.1016/j.gpb.2014.01. 003.

47. Xiong XD, Cho M, Cai XP, Cheng J, Jing X, Cen JM, et al. A common variant in pre-miR-146 is associated with coronary artery disease risk and its mature miRNA expression. Mutat Res - Fundam Mol Mech Mutagen . 2014;761:15-20. Available from: 10.1016/j.mrfmmm.2014.01.001.
48. Wang Y, Wang X, Li Z, Chen L, Zhou L, Li C, et al. Two single nucleotide polymorphisms (rs2431697 and rs2910164) of miR$146 \mathrm{a}$ are associated with risk of coronary artery disease. Int J Environ Res Public Health. 2017;14(5):4-10. PMID: 28489066. Available from: 10.3390/ijerph14050514.

49. Liu X, You L, Zhou R, Zhang J. Significant association between functional microRNA polymorphisms and coronary heart disease susceptibility\% UNKNOWN UNICODE CHARACTER 0202F (NARROW NO-BREAK SPACE) : a comprehensive meta-analysis

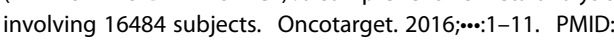
28035059. Available from: 10.18632/oncotarget.14249.

50. Xie X, Shi X, Xun X, Rao L. Association between microRNA polymorphisms and coronary heart disease : A meta-analysis. Herz. 2017;42(6):593-603. PMID: 27832287. Available from: 10.1007/s00059-016-4495-4.

51. Bao MH, Xiao Y, Zhang QS, Luo HQ, Luo J, Zhao J, et al Meta-analysis of miR-146a polymorphisms association with coronary artery diseases and ischemic stroke. Int J Mol Sci. 2015;16(7):14305-17. PMID: 26114385. Available from: 10 3390/ijms160714305.

52. Duan X, Zhan Q, Song B, Zeng S, Zhou J, Long Y, et al. Detection of platelet microRNA expression in patients with diabetes mellitus with or without ischemic stroke. J Diabetes Complications. 2014;28(5):705-10. PMID: 24908639. Available from: 10.1016/j.jdiacomp.2014.04.012.

53. Gatsiou A, Boeckel JN, Randriamboavonjy V, Stellos K. MicroRNAs in platelet biogenesis and function: implications in vascular homeostasis and inflammation. Curr Vasc Pharmacol. 2012;10(5):524-31. PMID: 22338566. Available from: 10.2174/157016112801784611.

54. Mitchell PS, Parkin RK, Kroh EM. Circulating microRNAs as stable blood-based markers for cancer detection. Proceedings of the National Academy of Sciences. 2008;105(30):1051310518. Available from: 10.1073/pnas.0804549105.

55. Laterza OF, Lim L, Garrett-Engele PW, Vlasakova K, Muniappa $\mathrm{N}$, Tanaka WK, et al. Plasma MicroRNAs as sensitive and specific biomarkers of tissue injury. Clin Chem. 2009;55(11):197783. PMID: 19745058. Available from: 10.1373/clinchem.2009. 131797.

56. Schulte $C$, Zeller T. microRNA-based diagnostics and therapy in cardiovascular disease-Summing up the facts. Cardiovasc Diagn Ther. 2015;5(1):17-36. PMID: 25774345. Available from: 10.3978/j.issn.2223-3652.2014.12.03.

57. Pordzik J, Pisarz K, Rosa SD, Jones AD, Eyileten C, Indolfi C, et al The potential role of platelet-related microRNAs in the development of cardiovascular events in high-risk populations, including diabetic patients: A review. Front Endocrinol (Lausanne). 2018;9(MAR):74. PMID: 29615970. Available from: 10.3389/fendo.2018.00074.

58. Ding $X$, Ding J, Ning J, Yi F, Chen J, Zhao D, et al. Circulating microRNA-122 as a potential biomarker for liver injury. Mo Med Rep. 2012;5(6):1428-32. PMID: 22427142. Available from: $10.3892 / \mathrm{mmr} .2012 .838$.

59. Tijsen AJ, Creemers EE, Moerland PD, de Windt LJ, van der Wal $A C$, Kok WE, et al. MiR423-5p as a circulating biomarker for heart failure. Circ Res. 2010;106(6):1035-9. PMID: 20185794. Available from: 10.1161/CIRCRESAHA.110.218297.

60. Yang S, Zhao J, Chen Y, Lei M. Biomarkers Associated with Ischemic Stroke in Diabetes Mellitus Patients. Cardiovascular toxicology. 2016;16(3):213-222.

61. Santilli F, Vazzana N, Liani R, Guagnano MT, DavìG. Platelet activation in obesity and metabolic syndrome. Obes Rev. 2012;13(1):27-42. PMID: 21917110. Available from: 10.1111/j. 1467-789X.2011.00930.x.

62. Santilli F, Vazzana N, Liani R, Guagnano M, Davì G. Platelet activation in obesity and metabolic syndrome. . doi:. Obes Rev. 2012;13(1):27-42. Available from: 10.1111/j.1467-789X.2011 00930.x.

63. Yang WJ, Yang DD, Na S, Sandusky GE, Zhang Q, Zhao G. Dicer Is Required for Embryonic Angiogenesis during Mouse Development. Journal of Biological Chemistry. 2005;280(1):9330- 
9335. Available from: 10.1074/jbc.M413394200.

64. Duan R, Pak C, Jin P. Single nucleotide polymorphism associated with mature miR-125a alters the processing of primiRNA. Human molecular genetics. 2007;16(9):1124-1131. Available from: $10.1093 / \mathrm{hmg} / \mathrm{ddm} 062$.

65. Albinsson $S$, Suarez $Y$, Skoura A, Offermanns $S$, Joseph $M$, Sessa WC. differentiation and function. 2011;30(6):11181126. Available from: 10.1161/ATVBAHA.109.200873. miRNAs.

66. Altuvia $Y$, Landgraf $P$, Lithwick G, Elefant N, Pfeffer $S$, Aravin $\mathrm{A}$, et al. Clustering and conservation patterns of human microRNAs. Nucleic Acids Res. 2005;33(8):2697-706. PMID: 15891114. Available from: $10.1093 / \mathrm{nar} / \mathrm{gki} 567$.

67. Zhu N, Zhang D, Chen S, Liu X, Lin L, Huang X, et al. Endothelial enriched microRNAs regulate angiotensin II-induced endothelial inflammation and migration. Atherosclerosis. 2011;215(2):286-93. PMID: 21310411. Available from: 10. 1016/j.atherosclerosis.2010.12.024.

68. Hartmann D, Thum T. MicroRNAs and vascular (dys)function. Vascul Pharmacol. 2011;55(4):92-105. PMID: 21802526. Available from: 10.1016/j.vph.2011.07.005.

69. Lovren F, Pan Y, Quan A, Singh KK, Shukla PC, Gupta N, et al. MicroRNA-145 targeted therapy reduces atherosclerosis. Circulation. 2012;126(11):81-90. PMID: 22965997. Available from: 10.1161/CIRCULATIONAHA.111.084186.

70. Lu M, Zhang Q, Deng M, Miao J, Guo Y, Gao W, et al. An analysis of human microRNA and disease associations. PLoS One. 2008;3(10):e3420. PMID: 18923704. Available from: 10.1371/journal.pone.0003420.

71. Nieuwdorp M, Stroes ESG, Meijers JCM, Büller H. Hypercoagulability in the metabolic syndrome. Curr Opin Pharmacol 2005;5(2 Spec. Iss):155-159. Available from: 10.1016/j.coph. 2004.10.003.

72. a Zimmerman G, Weyrich AS. Pathways to Altered Phenotype and Function. Arterioscler Thromb. 2008;28(3). Available from: 10.1161/ATVBAHA.107.160218.Signal-Dependent.

73. Schulte C, Molz S, Appelbaum S, Karakas M, Ojeda F, Lau DM, et al. MiRNA-197 and miRNA-223 predict cardiovascular death in a cohort of patients with symptomatic coronary artery disease. PLoS One. 2015;10(12):e0145930. PMID: 26720041. Available from: 10.1371/journal.pone.0145930.

74. JA W, N E, R P, JE F, JF K, KT, et al. Circulating cell and plasma microRNA profiles differ between non-ST-segment and STsegment-elevation myocardial infarction. Family medicine \& medical science research. 2014;2(2):108. Available from: 10.4172/2327-4972.1000108.

75. Goren Y, Meiri E, Hogan C, Mitchell H, Lebanony D, Salman N, et al. Relation of reduced expression of MiR-150 in platelets to atrial fibrillation in patients with chronic systolic heart failure. Am J Cardiol. 2014;113(6):976-81. PMID: 24462065. Available from: 10.1016/j.amjcard.2013.11.060.

76. Hollopeter G, Jantzen HM, Vincent D, Li G, England L, Ramakrishnan $\mathrm{V}$, et al. Identification of the platelet ADP receptor targeted by antithrombotic drugs. Nature. 2001;409(6817):2027. PMID: 11196645 . Available from: $10.1038 / 35051599$.

77. Gambaryan S, Kobsar A, Rukoyatkina N, Herterich S, Geiger J, Smolenski A, et al. Thrombin and collagen induce a feedback inhibitory signaling pathway in platelets involving dissociation of the catalytic subunit of protein kinase A from an NFkappaB-lkappaB complex. J Biol Chem. 2010;285(24):18352-63. PMID: 20356841. Available from: 10.1074/jbc.M109.077602.

78. Choi YC, Yoon S, Jeong Y, Yoon J, Baek K. Regulation of vascular endothelial growth factor signaling by miR-200b. Mol Cells. 2011;32(1):77-82. PMID: 21544626. Available from: 10.1007/ s10059-011-1042-2.
79. Somanath PR, Podrez EA, Chen J, Ma YI, Antoch M, Byzova TV. Deficiency in core circadian protein Bmal1 is associated with a prothrombotic and vascular phenotype. Journal of cellular physiology. 2011;226(1):132-40. Available from: 10.1002/jcp. 22314.Deficiency.

80. Shan SW, Lee DY, Deng Z, Shatseva T, Jeyapalan Z, Du WW, et al. MicroRNA MiR-17 retards tissue growth and represses fibronectin expression. Nat Cell Biol. 2009;11(8):1031-8. PMID: 19633662. Available from: $10.1038 / \mathrm{ncb} 1917$.

81. Fichtlscherer S, Rosa SD, Fox H, Schwietz T, Fischer A, Liebetrau $C$, et al. Circulating microRNAs in patients with coronary artery disease. Circ Res. 2010;107(5):677-84. PMID: 20595655. Available from: 10.1161/CIRCRESAHA.109.215566.

82. Peng $\mathrm{H}$, Zhong $\mathrm{M}$, Zhao W, Wang C, Zhang J, Liu X, et al. Urinary miR-29 correlates with albuminuria and carotid intimamedia thickness in type 2 diabetes patients. PLoS One. 2013;8(12):e82607. PMID: 24349318. Available from: 10.1371/ journal.pone.0082607.

83. van Rooij E, Sutherland LB, Thatcher JE, DiMaio JM, Naseem $\mathrm{RH}$, Marshall WS, et al. Dysregulation of microRNAs after myocardial infarction reveals a role of miR-29 in cardiac fibrosis. Proc Natl Acad Sci USA. 2008;105(35):13027-32. PMID: 18723672. Available from: 10.1073/pnas.0805038105.

84. Shiffman D, Rowland CM, Louie JZ, Luke MM, Bare LA, Bolonick $\mathrm{Jl}$, et al. Gene variants of VAMP8 and HNRPUL1 are associated with early-onset myocardial infarction. Arterioscler Thromb Vasc Biol. 2006;26(7):1613-8. PMID: 16690874. Available from: 10.1161/01.ATV.0000226543.77214.e4.

85. Ezzell RM, Kenney DM, Egan S, Stossel TP, Hartwig JH. Localization of the domain of actin-binding protein that binds to membrane glycoprotein $\mathrm{lb}$ and actin in human platelets. J Biol Chem. 1988;263(26):13303-9. PMID: 3138234.

86. Elgheznawy A, Fleming I. Platelet-enriched microRNAs and cardiovascular homeostasis. Antioxid Redox Signal. 2017;2017(9). Available from: 10.1089/ars.2017.7289.

87. Harris TA, Yamakuchi M, Ferlito M, Mendell JT, Lowenstein CJ. MicroRNA-126 regulates endothelial expression of vascular cell adhesion molecule 1. Proc Natl Acad Sci USA. 2008;105(5):1516-21. PMID: 18227515. Available from: 10. 1073/pnas. 0707493105.

88. Cavarretta E, Chiariello GA, Condorelli G. Platelets, endothelium, and circulating microRNA-126 as a prognostic biomarker in cardiovascular diseases: per aspirin ad astra. Eur Heart J. 2013;34(44):3400-2. PMID: 23391580. Available from: 10 1093/eurheartj/eht032.

89. Fasanaro P, D'Alessandra Y, Stefano VD, Melchionna R, Romani $\mathrm{S}$, Pompilio G, et al. MicroRNA-210 modulates endothelial cell response to hypoxia and inhibits the receptor tyrosine kinase ligand Ephrin-A3. J Biol Chem. 2008;283(23):15878-83. PMID: 18417479. Available from: 10.1074/jbc.M800731200.

90. Guduric-Fuchs J, O'Connor A, Cullen A, Harwood L, Medina $\mathrm{RJ}, \mathrm{O}$ 'Neill $\mathrm{CL}$, et al. Deep sequencing reveals predominant expression of miR-21 amongst the small non-coding RNAs in retinal microvascular endothelial cells. J Cell Biochem. 2012;113(6):2098-111. PMID: 22298343. Available from: $10.1002 /$ jcb. 24084 .

91. Fleissner F, Jazbutyte V, Fiedler J, Gupta SK, Yin X, Xu Q et al. Short communication: asymmetric dimethylarginine impairs angiogenic progenitor cell function in patients with coronary artery disease through a microRNA-21-dependent mechanism. Circ Res. 2010;107(1):138-43. PMID: 20489163. Available from: 10.1161/CIRCRESAHA.110.216770.

92. Plé H, Landry P, Benham A, Coarfa C, Gunaratne PH, Provost P. The repertoire and features of human platelet microRNAs. PLoS One. 2012;7(12):e50746. PMID: 23226537. Available from: 10.1371/journal.pone.0050746. 